Jurnal Poetika Vol. IV No. 2, Desember 2016

\title{
HASRAT NANO RIANTIARNO DALAM Cermin Cinta: KAJIAN PSIKOANALISIS LACANIAN
}

\author{
Ricky Aptifive Manik \\ Kantor Bahasa Jambi \\ rickymanik@gmail.com
}

\begin{abstract}
Abstrak
Karya sastra merupakan manifestasi hasrat pengarang. Dalam sejarahnya, hasrat terbentuk dari rasa kekurangan subjek. Menulis karya sastra merupakan upaya untuk menutupi kekurangan tersebut. Upaya itu dapat dilihat dalam pandangan pengarang akan ego-ego ideal di dalam karya-karyanya. Novel Cermin Cinta adalah sample untuk melihat apa dan bagaimana hasrat Nano Riantiarno. Tujuannya adalah menemukan apa yang menjadi pembayangan ego-ego ideal bagi Nano. Telisik hasrat ini akan menggunakan kajian Psikoanalisis Lacanian (PL). Melalui PL ini akan digunakan metode metafora dan metonimia dalam melihat penanda-penanda hasrat Nano dalam Cermin Cinta. Kajian ini menemukan bahwa hasrat menjadi penulis dan seniman menuntun Nano secara tak sadar pada penanda-penanda simboliklainnyasepertipenulisyang'pantangmenyerah', 'ulet', 'konsisten', 'tekun', 'rajin',dsb.Mendirikan kelompok teater dengan menjadi penulis lakon dan menyutradarainya ia dapatkan dari citraan Rendra, Putu Wijaya, Arifin C Noor, dan Teguh Karya merupakan hasratnya akan keutuhan yang ontologis bagi identitas tersebut. 'Kebebasan' menjadi objek a Nano untuk mendapatkan jouissance bagi dirinya.
\end{abstract}

Kata Kunci: Hasrat, Kebebasan, Psikoanalisis, Lacan, Nano Riantiarno

\section{Abstract}

Literary works known as authors' desire manifestation. In its history, a desire comes from the feeling of the lack of subject. Writing a literary work. becomes an effort to bide it. The effort can be seen through an author's point of view on ego ideal in his works. Novel of Cermin Cinta is chosen as a sample in order to search what and how Nano Riantiarno's desires are. The aim is to find out the reflecting of Nano's ego ideal. This study uses Lacanian Psychoanalysis (PL). Metaphor and metonymy will be used through PL in looking deeply the signs of Nano's desire in Cermin Cinta. This study finds out that a desire of becoming a writer and an artist has guided Nano unconsciously to other symbolic signs, such as being a 'tough', 'consistent', 'determined', 'diligent' writer, etc. His effort in setting up a theatre community where he becomes the characters writer and director which was reached from the images of Rendra, Putu Wijaya, Arifin C. Noor, and Teguh Karya becomes his desire about the ontological intactness for his identity. Besides, Freedom' becomes 'object a' of Nano to get jouissance for himself.

\section{Keywords: Desire, Freedom, Psychoanalysis, Lacan, Nano Riantiarno}

\section{Pendahuluan}

Lacan mengatakan bahwa apa yang menggerakkankehidupanmanusiaadalah hasrat. Manusia sejak dilahirkan hingga melepaskan diri dari kesatuan-kesatuan eksistensial dalam dunia Real selalu mengalami kekurangan-kekurangan (lack), manusia dianggap selamanya berlubang. Rasa kekurangan selamanya mengikuti-seperti hantu yang menggentayangi-kehidupan manusia. Padahal kesatuan eksistensial (dalam dunia Real) itu tidak akan pernah didapati kembali. Perasaan yang mendekam di alam ketidaksadaran ini melahirkan hasrat yang tak pernah habis terpuaskan.

Lalu, bagaimana melihat hasrat ini dalam sastra? Jika dikatakan segala tindakan manusia itu merupakan hasil/produksi dari hasrat, maka tindakan menghasilkan karya sastra oleh pengarang tersebut merupakan manifestasi dari hasratnya. Pengarang dalam pengertian 
Lacanian adalah subjek yang berkekurangan itu. Teori Lacan tentang subjek adalah bahwa manusia itu diwakili oleh bahasa, oleh objekobjek khusus yang disebut "kata-kata". Istilah teknis Lacan untuk "kata" adalah "penanda". Bilamana seseorang berbicara atau menulis, ia selalu mewujudkan diri dengan bahasa, dengan penanda-penanda. Penanda-penanda adalah satu-satunya cara subjek itu dapat mewujudkan dirinya (Hill, 2002: 29-30). Begitu pula dengan sastra yang merupakan penanda sebagai perwujudan diri si pengarangnya.

Dalam hal ini, slogan Lacan adalah "penanda mewakili subjek bagi penanda lainnya". Bila karya sastra dianggap sebagai penanda (bahasa) perwakilan subjek pengarang, maka ada penanda lainnya yang berbeda dari subjek pengarang. Bahasa (penanda) menjadi tujuan penting dalam kajian psikoanalisis Lacanian karena ketidaksadaran terstruktur seperti bahasa yang memainkan peranannya di dalam metafora dan metonimia. Dalam perspektif lacanian, seperti yang dikemukan oleh Faruk (2012:197), memahami karya sastra adalah usaha untuk menemukan ketidaksadaran subjek dalam mencari keutuhan/kepenuhan dirinya. Oleh karena kondisi ketidaksadaran itu tidak mungkin untuk diakses sepenuhnya, maka untuk dapat memahami karya sastra tersebut adalah dengan cara melihat bahasa karya sastra tersebut, yaitu melalui fenomena metafora dan metonimia. Melalui metafora dan metonimia yang digunakan sebagai alat atau media karya sastra oleh pengarang ini akan dapat ditemukan bagaimana struktur ketidaksadaran pengarang itu bekerja yang kemudian disebut sebagai hasratnya.

Dalam penelitian ini penulis mengambil sosok Nano Riantiarno selanjutnya yang penulis nilai sangat produktif dalam menghasilkan karya-karyanya. Artikel ini sendiri merupakan bagian dari hasil penelitian yang dilakukan dalam bentuk tesis S2 di jurusan Ilmu Sastra Fakultas Ilmu Budaya, Universitas Gadjah Mada dengan judul Hasrat N. Riantiarno dalam Trilogi Cermin Kajian Psikoanalisis Lacanian (2013).

Kebenaran hipotesis Lacan mengenai hasrat subjek yang selalu berkekurangan diuji pada sosok Nano dalam novel Cermin
Cinta (CC)-nya (2005). Novel CC merupakan kelanjutan dari novel Cermin Merah (CM) dan novel Cermin Bening (CB). Ketiga novel ini disebut sebagai trilogi Cermin.

Nano adalah seorang sastrawan yang lebih dikenal lewat naskah-naskah dramanya. Ia juga dikenal sebagai sutradara sekaligus pendiri Teater Koma (Anwar, 2005: 61). Selain menulis naskah drama untuk pentas teater Koma, ia juga menulis puisi, cerpen, skenario film dan novel. Meskipun tidak seproduktif menulis naskah drama, skenario filmnya yang berjudul Jakarta-Jakarta pernah memenangkan piala Citra pada Festival Film Indonesia tahun 1978. Dua novelnya yang berjudul Ranjang Bayi dan Percintaan Senja, meraih hadiah sayembara novel Majalah Femina dan Kartini (Anwar, 2005: 61).

Untuk menjaga produktivitasnya dalam menulis, dapat dipastikan bahwa, selain membaca, Nano juga menyerap banyak hal untuk dipelajari sebagai sumber inspirasi yang kemudian menjadi ide dalam tulisannya. Lingkungan sosial di sekitarnya, yaitu Jakarta merupakan hal-hal yang sering muncul sebagai ide-ide kreatif menulisnya, di samping pengetahuannya tentang sejarah, seni, budaya, psikologi, sosial, dan lain sebagainya. Kritikkritik sosial yang acap hadir dalam naskahnaskah drama dan pentas Teater Komanya seringkali membuat marah para penguasa Orde Baru. Akibatnya, Nano dan kelompok teaternya tak luput dari pencekalan-pencekalan yang berupa pelarangan pentas (Anwar, 2005: 70-72).

Akan tetapi, buah pencekalan tersebut tidak menyurutkan produktivitasnya. Karyakaryanya yang lahir justru banyak yang memperjuangkan identitas kaum pinggiran (orang-orang miskin di Jakarta, orang-orang yang dianggap 'abnormal' seperti kaum Lesbian, Gay, Biseksual, dan Transeksual, atau yang disingkat dengan LGBT dan orang-orang yang terkena dampak politik stigmatisasi seperti etnis Tionghoa dan keluarga PKI, seperti yang terlihat dalam naskah-naskah dramanya, yaitu trilogi Kecoa dan naskah-naskah yang disadur dari cerita negeri Cina (Sampek Engtay, Opera Ular Putih, dan Sie Jin Kwie). Hal ini menjadi bukti bahwa, keberadaan identitas kaum yang 
terpinggirkan atau bahkan diabsensi membawa kegelisahan pada diri Nano. Penulis menduga ada pertanyaan yang implisit pada diri Nano yang termanifestasi dalam karya-karyanya perihal identitas-identitas yang terpinggirkan. Misalnya, mengapa keberadaan kaum LGBT cenderung dianggap 'abnormal', 'prilaku menyimpang', dan 'sakit' di dalam lingkungan sosialnya. Pertanyaan tersebut tentu saja berlaku untuk identitas-identitas lain yang juga mendapatkan perlakuan yang sama: stigmatisasi. Diskriminasi yang terjadi terhadap kaum-kaum yang dipinggirkan telah membawa dampak akan hilangnya harmonisasi di dalam kehidupan manusia tersebut. Oleh sebab itu, penulis mengasumsikan bahwa kehilangan harmonisasi telah menjadi keresahan/kegelisahan Nano.

Asumsi lainnya adalah adanya satu perasaan persamaan identitas yang tertindas dalam sebuah wacana sosial bagi Nano sendiri. Itulah mengapa Lacan mengatakan (dalam Sarup, 2011) individu tidak terpisah dari masyarakat. Nano tidak bisa dipisahkan dari masyarakatnya. Masyarakat ada dalam diri setiap individu. Maka, jawaban atas kedua pertanyaan tersebut ada pada prinsip kekurangan (lack) Lacanian. Dalam bahasa Lacanian dikatakan sebagai subjek-subjek yang terbelah (\$). Wacana ini cenderung mengkonstruksi dalam bentuk perbedaan, seperti perempuan/laki-laki, yang baik/tidak baik, benar/tidak benar, normal/ tidak normal dan lain sebagainya oleh sebuah tatanan simbolik, seperti agama, masyarakat (adat), dan negara. Wacana yang terbentuk pada diri subjek pada fase yang disebut sebagai fase cermin, dimana seseorang akan melihat diri-diri yang ideal dalam konstruksi Yang Simbolik. Fase cermin Lacan ditafsirkan oleh Althusser (2010: 19-21) sebagai Ideological State Apparatus (ISA). Ideologi Aparatus Negara (ISA) menurut Althusser berbeda dari aparatus negara (State Apparatus, SA). SA memuat: pemerintah, administrasi, angkatan bersenjata, polisi, pengadilan, penjara, dsb yang kemudian disebutnya sebagai aparatus Negara Represif. ISA memuat: agama, pendidikan, keluarga, hukum, politik, serikat buruh, komunikasi, dan budaya. Perbedaan keduanya terletak pada praktiknya. Bila SA pada praktiknya lebih menonjol lewat represif, ISA lebih menonjol lewat ideologi.

ISA justru membuat diri subjek/ manusia/Nano terpenjara secara simbolik yang kemudian membuat dirinya menjadi split (terbelah), yakni diantara keinginan asali dan keinginan ISA (Yang Simbolik). Namun senyatanya, keinginan asali cenderung disimpan rapat-rapat agar tak mencuat keluar, yang dimunculkan hanya apa yang menjadi keinginan Yang Simbolik. Itulah sebabnya mengapa Lacan mengatakan bahwa ego itu ilusif. Keteganganketegangan akan kekurangan eksistensial secara terus-menerus berlangsung sepanjang hidup subjek/Nano.

Karya sastra dapat dijadikan media bagi pengarang dalam memanifestasikan hasrat ingin menjadi dan hasrat ingin memilikinya, yaitu dengan menghadirkan baik secara eksplisit maupun implisit tokoh-tokoh ideal dan dunia-dunia ideal di dalam karyanya, dimana subjek-subjek yang ada di dalamnya digambarkan atau dibayangkan memiliki keutuhan akan identitasnya. Jika secara eksplisit yang dihadirkan adalah tokoh-tokoh ironi atau dunia-dunia ironi, maka secara implisit atau yang tidak tampak adalah gambaran tentang yang ideal tersebut. Hal mengenai yang ideal ini muncul sejak pengenalan diri pada cermin dan selalu menyertai dalam kehidupan manusia (baca: pengarang) itu.

Oleh karena itu, menulis karya sastra adalah sebagai kanal tempat mengalirnya hasrat Nano selaku pengarang. Maka dari itu, menelisik aspek intrinsik yang ada di dalam karya tersebut menjadi hal penting, sebab bahasa yang menjadi media dalam karya tersebut merupakan alat penting dalam telisik psikoanalisis Lacanian. Menelisik aspek intrinsik ini menjadi jendela dalam melihat persoalan wacana sosial yang disampaikan oleh pengarang melalui karyanya yang merupakan metafora-metafora hasrat pengarang yang termanifestasikan.

Berdasarkan pemaparan di atas, maka masalah yang penulis rumuskan dalam penelitian ini hanya satu hal pokok saja, yaitu: apa dan bagaimana hasrat Nano sebagai hasrat subjek yang berkekurangan (lack) di dalam Cermin Cinta. Tujuan hasil penelitian 
ini adalah mengidentifikasi hasrat Nano dan mendeskripsikan bagaimana hasrat itu terbentuk yang dimanifestasikannya di dalam Cermin Cinta.

\begin{tabular}{lll}
\multicolumn{2}{c}{ Nano lebih dikenal sebagai seorang } \\
dramawan atau teaterawan. & Tidaklah \\
mengherankan bila penelitian & terhadap
\end{tabular}
karya-karya Nano lebih banyak dilakukan pada naskah-naskah dramanya. Dari sekian banyak penelitan yang dilakukan terhadap karya-karya Nano, belum ada yang melihat dan menemukan apa yang membuat Nano sebegitu produktifnya. Syaiful Anwar dalam tesis S2 (UGM) yang kemudian dibukukan dengan judul N. RIANTIARNO: Dari Rumah Kertas Ke Pentas Dunia (2005) hanya menuliskan mengenai siapa Nano dan kehidupannya dalam menghasilkan karya-karya, serta faktor-faktor yang menyebabkannya menjadi seniman teater Indonesia. Penelitian ini belum sampai pada hal yang substansial mengenai apa yang menjadi keinginan (hasrat) Nano yang sesungguhnya.

Penelitian terhadap CC ini adalah penelitian dengan metode Psikoanalisis Lacanian. Metode ini berangkat dari asumsi teoretik bahwa identitas manusia (subjek) atau masyarakat terbentuk dari hasratnya yang merupakan produk ketidaksadaran. Apa yang membentukdiri(ego) berasaldariketidaksadaran. Faruk (2012: 196) mengemukakan bahwa teori psikoanalisis Lacan menganggap alam bawah sadar manusia selalu dalam keadaan "kurang", merasa ada yang hilang sehingga tumbuh hasrat dan usaha yang terus-menerus untuk menutupi kekurangan itu, menemukan kembali apa yang hilang, membuat manusia kembali lengkap, sempurna, utuh, menemukan identitasnya, menjadi dirinya kembali.

Karya sastra yang diproduksi pengarang juga merupakan produk hasrat pengarang/ manusia sebagai subjek. Untuk mendapatkan konsep diri manusia (subjek) dari lahir menuju dewasa yang dinamakan sebagai Kompleks Oedipus, manusia harus menempuh tiga fase yang berhubungan dengan tiga ranah (register) atau tatanan (order) psikisnya, yaitu: fase praoedipal pada tatanan Real (the Real), fase cermin pada tatanan Imajiner (the Imaginary), dan fase odipal pada tatanan Simbolik (the Simbolic).
Ketiga tatanan ini senantiasa mengiringi setiap langkah hidup manusia itu. Dikatakan bahwa, subjek Lacanian adalah subjek yang terbelah (split), kekurangan, dan tidak utuh. Dalam konsep kekurangan ini, Lacan melihatnya ada determinasi antara Yang Real dan Yang Simbolik. Oleh karena itu, subjek ini terus mencari kepastian diri, yang seringkali mengacu pada Yang Lain. Dalam usaha pencarian inilah subjek mengkonstruksi dirinya terhadap realitas. Pengkonstruksian diri ini mengandung hasrat (desire) pada diri subjek. Faruk (2012: 196) mengatakan bahwa bahasa merupakan sebuah tatanan kultural yang menanamkan subjektivitas bagi manusia, membuat manusia menemukan identitas atau dirinya. Namun, apa yang dilakukan bahasa pada subjek itu bersifat mendua: di satu pihak memberikan rasa subjektivitas, di lain pihak menjauhkan sang subjek dari diri asalinya. Bahasa, dengan demikian, justru memperkuat rasa kurang dan rasa kehilangan di atas.

Dengan menemukan dan mengidentifikasi hasrat yang ada dalam CC ini, maka melalui metode subjek Lacanian ini pula akan ditemukan apa yang menjadi hasrat Nano sebagai subjek yang berkekurangan. $\mathrm{Hal}$ ini penting karena hasrat akan menentukan arah 'menjadi' seseorang dan apa yang ingin 'dimiliki'.

\section{Konsep Diri}

Untuk mendapatkan konsep diri, Lacan membagi proses pembentukan subjek itu ke dalam tiga fase yang memiliki hubungan dengan tiga ranah atau tatanan dalam psikis manusia. Yang pertama dinamakan fase pra-odipal pada tatanan Real, fase cermin pada tatanan Imajiner, dan fase odipal pada tatanan Simbolik.

Pada fase pra-odipal, seperti halnya Freud, Lacan juga mengatakan pada fase ini bayi belum mengenali dirinya dan batasan egonya. Diri bayi merasa satu dengan diri ibunya bahkan juga dengan diri yang lain, tak ada yang membedakan. Bayi dan ibu masih merupakan kesatuan. Dalam fase cermin, terjadi tiga hal penting. Pertama adalah pada saat bayi menyadari keterpisahannya dengan ibunya. Hal ini membuat sang bayi merasa kehilangan, 
kekurangan, dan ingin menyatu kembali dengan ibu. Akan tetapi, bayi masih belum mengetahui konsep "diri”"nya. Hal ini membawa bayi pada hal penting berikutnya, yaitu dari kebutuhan menjadi permintaan.

Kedua, dikarenakan kebutuhannya tak lagi secara otomatis terpenuhi, maka sang bayi harus memintanya. Akan tetapi, bayi tak dapat mengartikulasikan permintaannya dengan tepat, akibatnya sang ibu atau siapa pun tidak dapat memenuhi permintaannya. Di sini, bayi hanya bisa menangis karena bayi belum memiliki bahasa.

Hal ketiga yang terpenting lainnya adalah dimana terjadi proses identifikasi pada bayi. Imajiner adalah istilah yang dipakai Lacan untuk menyebut proses pembentukan subjek yang didominasi oleh identifikasi dan dualitas, sebelum pengenalan pada bahasa (Hartono, 2007: 23). Identifikasi menurut Lacan (Lacan, 1977: 2) adalah suatu transformasi yang terjadi pada benak subjek saat ia membayangkan suatu citra, seperti yang ditulisnya dalam artikel panjangnya, Ecrits: "the transformation that takes place in the subject when he assumes an image". Identifikasi pertama kali yang dilakukan oleh bayi pada saat dirinya melihat cermin adalah mencampuradukan bayangannya dengan bayangan orang lain. Di sinilah bayi mengalami kesalahmengertian (misrecognition) terhadap dirinya sendiri. Namun pada saat itulah bayi mulai belajar untuk menciptakan konstruksi suatu pusat atau yang Lacan sebut sebagai 'ego ideal'. Kemudian, ketika si anak tumbuh dewasa, ia akan terus membuat identifikasi imajiner dengan objek-objek yang ditemuinya.

Fase ketiga adalah fase odipal atau tatanan Simbolik. Pada fase inilah anak harus mengalami kastrasi, dimana anak harus berpisah dari ibunya. Ibu dipandang sebagai Liyan ${ }^{1}$ sebab ibu tak lagi dilihat sebagai satu-kesatuan pada diri sang anak. Kemunculan ayah memperparah hubungan antara ibu dan anak. Kehadiran 'ayah

\footnotetext{
${ }^{1}$ Liyan untuk 'L' besar merupakan pusat dari otoritas kultural Simbolik. Freud menamakannya sebagai Phallus. Sedangkan liyan dengan ' 1 ' kecil merujuk pada objek penyebab hasrat yang disebut oleh Lacan sebagai obyek a. Pembedaan antara kedua ini dapat dilihat dalam Jacques Lacan, The Seminar of Jacques Lacan, Book II. The Ego in Freud's Theory and in the Technique of Psycoanalysis, 1954-1955, peny. J-A. Miller, terj. S. Tomaselli (NY, London: W.W. Norton \& Company, 1988), hh. 243-247.
}

simbolik' menyebabkan anak kehilangan objek hasratnya, yakni ibu (liyan).

Konsep hasrat ini juga berangkat dari suatu kegelisahan (anxiety). Gagasan kegelisahan selalu merupakan reaksi akan suatu kehilangan. Kehilangan merupakan gagasan yang fundamental dalam konsepsi subjek dalam psikoanalisis Lacanian. Namun kehilangan di sini merupakan suatu persepsi atau kesalahmengiraan tentang adanya yang hilang. Apa yang hilang itu? Tidak lain adalah objek-penyebab-hasrat, atau yang disebut Lacan sebagai objek a (objek petit a). Huruf "a" merupakan singkatan bahasa Perancis "autre" (other). Hasrat Lacanian selalu berkaitan dengan yang lain. Mengakuisisi akan objek ini dapat memberikan suatu jouissance. Arti jouissance di sini tidak dapat diartikan sebagai "kenikmatan" saja, karena dalam konteks Lacanian, jouissance seperti kenikmatan yang paradoksal: di satu sisi membawa nikmat, tetapi di sisi lain membawa derita.

Untuk dapat memahami bagaimana subjek terus menerus mencari objek $a$ yang senyatanya tidak akan pernah ia dapatkan adalah dengan memahami tentang fase cermin kedua Lacanian: Kompleks Odipus dan Bahasa. Pada fase cermin yang kedua ini anak belajar konsep citra. Fungsi cermin, pada tahap Kompleks Odipus dipresentasikan oleh orang tua. Artinya, orang lain pertama yang memberi identitas pada diri subjek adalah orang tua, khususnya ibu. Triangulasi Freud dalam menjelaskan relasi antara anak-ibu-ayah ditransformasikan oleh Lacan. Ayah biologis Freud diterjemahkan Lacan sebagai ayah simbolis dengan konsep "atas-nama-ayah". Konsep "atas-nama-ayah" adalah representasi dari semua bentuk jejaring kultural yang menentukan identitas anak. Kompleks Odipus dilihat sebagai momen dimana anak menyadari diri, orang lain, dan dunia.

Bahasa merupakan representasi jejaring kultural yang paling dominan dalam mendefenisikan subjek. Menurut Lacan, subjek ditentukan oleh bahasa, malahan subjek tidak mungkin ada tanpa bahasa. Dengan kata lain, tidak ada subjek yang bebas dari bahasa. Semua 
subjek tenggelam dalam bahasa dan tidak pernah lepas dari bahasa sehari-hari. Semua manusia mempresentasikan diri melalui bahasa dan bahasa adalah jalan menuju domain sosial (Hartono, 2007: 26-27). Dengan tenggelam ke dalam bahasa, manusia masuk ke dalam "permainan bahasa" dengan segala atribut linguistiknya. Permainan atribut bahasa inilah yang kemudian menentukan identitas subjek: menentukan wilayah sadar (Ego) subjek. Ada dua cara kerja bahasa dalam memengaruhi identifikasi subjek. Pertama, bahasa yang bekerja dengan hukum pembedaan (metonimia). Kedua, adalah fungsi metaforisitas penanda.

Metafora dan metonimia merupakan dua jenis negosiasi utama yang berlangsung pada penanda-penanda. Dalam pemikiran Lacan, metonimia terkait dengan cara penandapenanda itu terhubung dengan penanda lain dalam sebuah rantai dan akhirnya dengan seluruh jaringan memberikan jalur tempat bekerjanya identifikasi dan hasrat. Bracher (2009) mengatakan bahwa metonimia adalah sebuah fungsi yang dengannya diskursus membentuk persekutuan dan pertentangan pada penanda-penanda ini.

Menurut konsep bahasa Lacanian, suatu penanda selalu menandakan penanda lain; tidak ada kata yang bebas dari metaforisitas (metafora adalah penanda yang menandakan penanda lain). Lacan bicara tentang glissement (keterpelesetan, ketergelinciran) dalam mata rantai penandaan, dari penanda yang satu ke penanda yang lain. Karena setiap penanda dapat menerima pemaknaan, maka tidak pernah ada makna yang tertutup, makna yang memuaskan (Sarup, 2009: 10). Metafora merepresentasikan salah satu cara yang digunakan untuk menstruktur pelbagai macam wacana.

\section{Cinta sebagai kehidupan dan kematian}

Novel CC ini digambarkan oleh Nano sebagai kisah akhir dari perjalanan hidup si Aku, Arsena. Cara narator yang digunakan pengarang dalam menuliskan kisahan seperti alam pikiran/ ingatan yang muncul tanpa keteraturan. Secara keseluruhan, inilah yang tampak dari novel trilogi Cermin ini. Pikiran yang muncul secara tidak runut tergambar dari alur ketiga novel tersebut. Gambaran-gambaran peristiwa ini seperti hasrat subjek yang terkadang muncul begitu saja.

Gambaran tentang hasrat yang selalu bergerak di dalam novel CC ini membuktikan bahwa subjek Lacanian akan senantiasa mengalami split, sekalipun identitas-identitas yang diakuisisinya telah menemui kemapanan (diterima secara Yang Simbolik). Novel CC sendiri bercerita tentang tokoh Arsena yang merasa kesepian setelah ditinggal mati oleh istri, sahabat, adik, dan kakaknya yang telah berada dan mengisi kehidupannya yang penuh konflik dalam novel sebelumnya. Di dalam CC ini Nano hendak menggambarkan bahwa cinta menjadi suatu yang diinginkan setiap manusia. Cinta seolah menawarkan suatu kebahagiaan dalam hidup manusia. Manusia seperti tidak dapat hidup tanpa cinta.

Selain Cinta, novel CC ini juga menceritakan tentang kematian. Bagi Lacan, kematian adalah suatu obat bagi derita hidup. Akan tetapi, kematian pada satu sisi menggoda untuk dihampiri, di sisi lain manusia takut menuju ke sana. Novel CC ini memperlihatkan dua naluri yang terdapat pada diri manusia itu, yaitu cinta sebagai kehidupan dan kematian. Dua wacana yang terdapat dalam novel ini menjadi poin penting dalam membahas dan melihat bagaimana hasrat Nano itu muncul.

\section{Cinta sebagai Permintaan (demand)}

Sebelum bayi dapat membedakan konsep keliyanan secara utuh, yaitu belum memiliki kemampuan membedakan antara dirinya dan liyan secara biner, bayi memasuki tahap baru berupa permintaan (demand). Permintaan menurut Lacan adalah sesuatu yang tidak dapat atau tidak mungkin terpenuhi. Apa yang diminta oleh anak adalah sesuatu yang tidak ada. Anak akan mencari sesuatu yang tidak diberikan kepadanya.

Cinta adalah objek permintaan. Jika permintaan adalah sesuatu yang tidak dapat terpenuhi, maka cinta itu juga tidak mungkin bisa terpenuhi. Cinta adalah suatu objek yang selalu menjadi permintaan subjek. Sayangnya, objek cinta ini tidak pernah didapat dan 
diberikan oleh kita. Sesorang yang mencintai kita atau kita yang mencintai orang lain adalah dalam keadaan permintaan, yaitu kehendak untuk memberikan sesuatu tetapi tidak dapat diberikan. Keadaan inilah yang tergambar diawal novel CC ketika sahabat, adik, kekasih, dan kakak yang telah mati berkumpul seperti hantu di dalam imajinasi Arsena. Gambaran tentang permintaan objek cinta ini terlihat disaat tokoh-tokoh ini berdiskusi mengenai cinta. Pandangan mengenai cinta oleh tokohtokoh hantu ini menggambarkan permintaan yang tak terpenuhi tersebut.

\section{"Jadi?" Tanya Herman menggoda. Mata dikejap-} kejapkan. "Cinta adalah...."

Edu menyabet cepat, "...kerelaan yang tulus. Kekuatan, pencipta rasa sabar, sehingga kita tetap mendampingi pasangan sampai tubub menua dan wajah keriput. Sampai salah satu mati bahagia. Cinta babkan mampu mewujudkan yang tak mungkin menjadi mungkin...." "Tidak, ah. Itu bukan cinta, tapi siksaan," sergah Herman.

"Bagiku ketulusan," Edu membela diri. "Tike merasa terpaksa jangan IBodhikan. Tinggalkan, pergilah, ke mana pun, jangan terus mendampingi pasangan. Lalu kita tahu, itu tentu bukan cinta, tapi ketidakpedulian." (CC, hlm. 16).

Penanda-penanda yang menjadi objek permintaan pada kutipan ini dapat dilihat pada penanda 'kerelaan', 'tulus', 'kekuatan', 'rasa sabar', 'bahagia', 'setia, dan 'yang tak mungkin menjadi mungkin'. Objek ini yang menjadi kehendak Edu untuk diberikan kepada Arsena karena dirinya mencintai Arsena. Tetapi kehendak untuk memberikan penanda itu tidak terpenuhi atau terberikan, pun sebaliknya, permintaan akan penanda itu tidak akan terpenuhi, baik bagi Edu maupun bagi Arsena. Edu ingin memberikan sesuatu yang barangkali tulus dan kebahagiaan untuk Arsena, tetapi tidak dapat diberikan. Hal ini seperti yang dilakukan Edu saat memberikan sanggar teater yang dibelinya dari gudang kerupuk untuk Arsena, tetapi pemberian itu ditolak oleh Arsena. Tindakan Edu ini merupakan tindakan untuk memberikan sesuatu atas dasar cintanya kepada Arsena. Tindakan ini adalah salah satu bentuk permintaan manusia akan keinginannya yang hakiki, yaitu mencintai dan dicintai.

Hill (2002: 69) mengatakan bila sesorang telah berhasil melampaui permintaannya, ia dapat mengatakan keinginannya. Orang seperti itu dapat mengatakan kepada Anda apa yang diinginkannya dan bagaimana keinginan itu mendorong hidupnya. Tetapi banyak orang hidup dalam keadaan semacam tak sadar, setengah tidur setengah jaga, hampir tidak mengetahui apa yang sebenarnya mereka mau. Mereka tidak mengetahui keinginan mereka sendiri dan tidak mengikutinya. Dari gambaran kisah cinta tokoh dalam novel ini menandakan bahwa Nano telah melampaui permintaannya. Persoalan cinta Edu, Hilman, Arsena, dan Nina merupakan gambaran bahwa ada sesuatu yang tetap tidak bisa diberikan dan diterima.

Nano sepertinya sadar bahwa pemintaannya akan cinta tak sepenuhnya bisa didapat. Namun persoalan cinta baginya harus dijaga dan diminta, sebab jika tidak ada permintaan, maka orang tidak dapat saling mencintai. Dari hal permintaan yang telah dilampaui inilah mengindikasikan bahwa Nano mengetahui keinginannya, yaitu dengan menjadi manusia yang menginterpelasi penanda-penanda yang memiliki kualitas penanda 'cinta', seperti 'rendah hati', 'jujur', 'tulus', 'sabar', 'rela', 'setia', dst. Penanda-penanda ini adalah indikasi keinginan Nano untuk menjadi orang yang penuh cinta, keinginan untuk memberikan sesuatu yang tidak pernah ada. Lebih 'ekstrim'nya, Nano ingin seperti “tuhan”, sosok ideal akan cinta kasih itu. Kutipan di bawah ini dapat mengindikasikan pandangan Nano tentang cinta yang harus menjadi milik manusia itu. Nano menggunakan sudut pandang melalui tokoh Edu yang menuliskan memoarnya.

“Cinta adalab 'barang halus' yang dicipta oleh perasaan paling halus. Memang sering kali tidak masuk di akal dan mustabl. Tapi, cinta memang seperti itu. Jika kita mencintai seseorang, apapun yang kita IBodhikan harus semata-mata dengan, dari dan cinta. setiap kita menatap, yang kita lihat hanya cinta, cemin yang kita tatap setiap bari pun, tentu akan memancarkan aura cinta. dan, bayangan kita dalam cermin adalah 
ekspresi dari cinta. setiap tindakan kita adalah cermin dari cinta. cermin cinta." (CC, hlm. 234)

Permintaan atas cinta adalah permintaan atas penyatuan diri setelah mengalami dan menyadari keterpisahan diri atas ibu semasa bayi yang kemudian menciptakan konsep keliyanan. Kesadaran tentang keterpisahan ini atau kenyataan tentang keliyanan menimbulkan kecemasan dan perasaan akan kehilangan (loss). Apabila cinta itu diartikan oleh katakata (penanda) yang terdapat dalam CC tersebut, maka kehidupan menjadi utuh, tidak ada konflik, sebab semua orang bertindak berdasarkan penanda-penanda itu. Oleh sebab itu, cinta adalah metafora dari kepenuhan dan keutuhan. Itu sebabnya ada lirik lagu "hidup tanpa cinta bagai taman tak berbunga", gersang, tidak indah atau tidak menarik. Cinta menjadi sesuatu yang dicari-cari baik oleh pengasong rokok atau pejabat korup sekalipun. Tidak heran jika tema cinta menjadi sesuatu yang menarik untuk diperbincangkan atau diceritakan. Permintaan tetaplah permintaan yang menurut Lacan sesuatu yang tidak didapatkan. Jika cinta adalah metafora akan kepenuhan bagi diri, cinta hakikatnya menjadi tidak ada. Manusia hanya mencari cinta untuk kepenuhan dan keutuhan dirinya. Cinta yang didapat (semisal dari kekasih atau orang tua) hanyalah ilusif, sebab manusia akan mencarinya lagi dan lagi. Ia akan terus berusaha mencari cintacinta yang lain guna menutupi kekurangan pada dirinya. Cinta menjadi kerinduan pada fase Real sebab cinta menjanjikan kepenuhan akan diri. Hill (2002: 69) mengatakan bahwa permintaan subjek akan cinta tidak pernah dapat diartikulasikan dengan semestinya karena permintaan, atau cinta, adalah permintaan akan sesuatu objek yang tidak benar-benar ada. Cinta adalah yang kosong, namun berkemampuan membuat utuh-penuh. "YangKosong" ini bisa pula kita dekatkan dengan ketulusan. Sesuatu yang 'letting be seen'. Cinta inilah sebenarnya yang menyebabkan 'Ada'. Hanya karena cinta, manusia ada. Eros menembakkan panahnya dan membuat manusia saling berpasangan dan melahirkan manusia lain. Cinta adalah spirit dari 'Ada', ia menjadi 'alasan' bagi manusia untuk tetap bertahan dalam kehidupannya (Audifax, 2010: 164).

\section{Cinta sebagai Objek yang Hilang}

Objek menurut Lacan sebagai sesuatu yang hilang. Meja yang kosong menandakan ada objek yang hilang. Begitupula dengan bekas luka terkena pisau di tangan yang menandakan ada objek pisau yang hilang. Subjek terdiri dari objek-objek yang tak ada. Objek ini memiliki arti khusus bagi seorang subjek. Jika cinta membuat 'Ada'nya manusia, maka cinta menjadi sesuatu yang diperlukan manusia untuk keberlangsungan hidupnya. Cinta adalah objek yang diperlukan oleh subjek.

Pada pembahasan sebelumnya, cinta menjadi sesuatu yang diinginkan. Bagi Nano, manusia yang hidup dengan cinta dan cinta sebagai cermin kehidupan akan membawa pada kehidupan yang damai, harmonis, dan tenteram. Akan tetapi, apabila cinta itu hilang dalam diri seseorang, dapat menyebabkan orang-orang tidak lagi menghargai orang lain, orang-orang akan mengabaikan kemanusiaan. Hal ini menimbulkan kegelisahan bagi Nano. Sebab, gagasan kegelisahan (anxiety) menurut Lacanian merupakan reaksi dari suatu kehilangan. Kehilangan adalah sesuatu yang dipersepsi salah oleh subjek.

Contoh yang diberikan Lacan tentang sesuatu yang hilang ini adalah ketertarikan Alcibiades pada Socrates (1977:322-323). Alcibiades percaya bahwa pada diri Socrates terdapat harta karun yang perlu dimiliki. Meskipun Socrates telah mengatakan bahwa dirinya "tidak tahu apa-apa", Alcibiades tetap saja bersikeras untuk mendapatkan harta karun tersebut, yakni dengan menjadi pengikut setia Socrates. Ia percaya dengan mengakuisisi harta karun itu dapat mengisi sesuatu yang hilang supaya apa yang menjadi bayangan ideal tentang dirinya dapat terpenuhi. Sayangnya, Alcibiades tidak pernah mendapatkan harta karun tersebut karena memang tidak ada. Kesalahmengiraan inilah yang membuat Alcibiades percaya buta dan terus-terusan menggali harta karun tersebut. Ketidakmungkinan untuk mendapatkan harta karun ini (objek a) yang pada akhirnya memproduksi 
perasaan kekurangan secara terus-menerus.

Novel CC ini mengindikasikan akan kegelisahan diri Nano, terutama kegelisahan akan hilangnya objek-penyebab-hasratnya. Cinta dalam novel ini sama halnya dengan Socrates dan Nano sebagai Alcibiades. Nano mengira dengan mengakuisisi cinta ini akan dapat mengisi sesuatu yang kurang pada dirinya dan menjadikan sesuatu yang ideal bagi dirinya. Kegelisahan yang terjadi pada subjek Lacanian bukan bereaksi terhadap kehilangannya, melainkan potensi/bahaya kehilangan objek-penyebab-hasrat itu. Jika cinta itu hilang, maka ada bahaya yang ditimbulkan dari kehilangan itu. Inilah yang tergambar dari kegelisahan Nano akan dampak kehilangan objek a yang terbungkus (enveloping) dalam cinta, seperti pandangan yang terdapat dalam bab Tentang Cinta, sebuah bab yang berisi tentang naskah lakon yang diciptakan oleh Arsena ${ }^{2}$.

"Bodhi menimpali, hati resah. "Membaca koran pagi. Menduga-duga demonstrasi jenis apa lagi yang akan digelar. Siapa lagi bakal kena tudub melanggar HAM dan korupsi. Siapa pengacara yang akan mengurus perkara. Berapa harga kasus, komisi, dan jumlah uang sogokan agar perkara bisa cepat masuk peti es...

"...Mencatat semua kegaduhan politik. Hiruk pikuk yang bikin langit resah, bumi gonjang-ganjing. Siapa menjegal siapa, sambil mengatasnamakan rakyat. Dan rakyat yang diatasnamakan, hanya bisa gigit jari. Tidak dapat apa-apa. Busung lapar di mana-mana." (CC, hlm. 248-249)

Inilah gambaran yang terjadi menurut pandangan Nano jika cinta itu hilang. Orang-orang akan bertikai satu dengan yang lainnya. Tidak ada cinta, berarti tidak ada 'keadilan', 'kejujuran', 'kebaikan', 'keharmonisan', 'ketenteraman', 'keamanan', 'keindahan', 'kebersamaan', 'kesukacitaan', 'kebahagiaan', dst. Gambaran yang terjadi adalah demonstrasi, kegaduhan, hiruk-pikuk,

\footnotetext{
${ }^{2}$ Naskah lakon ini berjudul asli "Tanda Cinta" karya N. Riantiarno yang menjadi produksi ke-105 Teater Koma. Dipentaskan di GKJ pada tanggal 27-29 Juli 2005 sebagai peringatan harijadi Nano dan Ratna. Penulis sendiri terlibat pada pementasan itu.
}

keresahan, gonjang-ganjing, dan kelaparan.

\section{Kematian: Kegelisahan akan Hilangnya Objek $a$}

Dimensi psikis menurut Sigmud Freud terbagi dalam tiga kategori yaitu $i d$, ego, dan super ego. $I d$ terdapat dalam fase yang disebut oleh Freud sebagai fase oral. Id merupakan pusat dari segala kenikmatan. Kenikmatan yang timbul dari kegiatan memasukan sesuatu ke mulut. Ada dua naluri dasar yang terdapat dalam Id yang merupakan lapisan psikis paling dalam sejak manusia lahir, yaitu eros (naluri kehidupan) dan thanatos (naluri kematian). Id tidak mengenal aturan, bahasa, hukum, prinsip, apalagi budaya; yang dipikirkannya hanyalah pemenuhan naluri-nalurinya-kenikmatan ${ }^{3}$.

Kedua naluri manusia inilah yang terdapat dalam novel CC yang berbicara mengenai cinta (kehidupan) dan kematian. Nano menggambarkan dua persoalan yang dialami manusia ini dalam hidupnya. Kebertahanan manusia akan kehidupannya dikarenakan oleh cinta. Cinta menjadi permintaan dalam hidup manusia agar manusia selalu ada dengan keinginan-keinginannya. Cintalah yang memunculkan hasrat-hasrat manusia untuk keberlangsungan hidupnya. Jika manusia dalam Lacanian dikatakan sebagai subjek, maka cinta adalah objek, begitupula dengan kematian. Objek dalam pengertian Lacan bukanlah benda-benda jasmani seperti misalnya meja atau batu bata, melainkan sesuatu yang mempunyai arti penting khusus untuk keinginan seorang subjek. Objek menurut Lacan adalah sesuatu yang hilang. Manusia mengalami kehilangan dan manusia membutuhkan cinta untuk memberikan sesuatu pada diri yang hilang itu.

Subjek terdiri atas objek-objek yang tak ada, atas barang-barang yang tercecer dan hilang, dan kerap kali dibayangkan oleh subjek berada pada orang-orang lain. Nano menggambarkan hantu-hantu yang datang pada bab Percakapan

\footnotetext{
${ }^{3}$ Hizkia Yosias Simon Polimpung menyarikannya dengan sangat baik dari buku Freud yang berjudul The Ego and The Id (1923), dalam The Standard Edition of the CompletePsychological Works of Sigmund Freud, Vol. XIX (London: Hogarth Press, 1957) ke dalam tesis S2-nya yang berjudul Psikoanalisis Paradoks Kedaulatan Kontemporer-Kasus Kebijakan Global War on Terror Amerika Serikat Semasa Pemerintahan George W. Bush Jr. Tesis S2, UI, hlm. 57.
} 
Malam adalah objek-objek yang tak ada, tapi dibayangkan ada sebagai perwujudan yang hilang pada diri subjek. Tokoh-tokoh yang mati adalah tokoh-tokoh yang digambarkan sebagai orangorang terdekat tokoh Arsena. Tokoh-tokoh ini merupakan Liyan yang Simbolik bagi tokoh satu dengan tokoh yang lainnya karena sebagai yang mengakui dan mencintai keberadaan diri. Tokoh Arsena digambarkan memiliki eksistensi yang substansial karena adanya tokoh-tokoh ini (Edu, Hilman, Herman, Anto, Nina, Nancy, dan Niken). Gambaran tentang tokoh-tokoh ini menandakan kesadaran Nano akan adanya Yang-Lain/Liyan. Keberadaan Yang Lain ini dibutuhkan untuk menjaga eksistensi diri. Subjek ada dikarenakan ada objek, begitupula dengan konsep budak-majikannya Hegel, majikan ada karena pengakuan dari budak.

Tokoh Hilman, meskipun keberadaan dirinya diakui dan dicintai oleh Liyan karena profesinya sebagai sutradara dan penulis skenario ternama, tetapi dirinya tetap merasakan kehilangan eksistensi ketika cintanya tidak disambut oleh Nina. Sama halnya dengan tokoh Edu dan Nancy yang juga merasa kehilangan eksistensi terhadap Arsena. Perasaan kehilangan eksistensi ini membuat tokoh Hilman, Edu, Nancy digambarkan memilih jalan kematiannya sendiri. Tokoh Nina juga digambarkan dengan cara memilih mati setelah merasa bersalah atas kematian Hilman. Arsena merasa kehilangan eksistensi dirinya setelah istri yang dicintainya, Niken, meninggal dunia. Niken bagi Arsena adalah Liyan yang Simbolik itu.

"Beberapa waktu yang lalu, Niken meninggal dunia. Kini Bodhi sendiri. Siapa yang merancang jalan hidup seperti ini? Bodhi tidak merancangnya. Pasti ada yang merancang. Kulakoni jalan hidup tanpa kesiagaan, toh semuanya berjalan baik. Bodhi bahagia, ketika Niken masib ada. Lalu, apa guna bidup tanpa Niken? Segalanya tidak berarti lagi." (CC, hlm. 331).

Tokoh-tokoh tersebut satu sama lain adalah Liyan yang Simbolik yang menjadi media bagi keberadaan diri. Ketika Liyan yang Simbolik ini hilang maka diri juga mengalami kehancuran eksistensi. Eksistensi diri menjadi tidak ada tanpa ada pengakuan dari Liyan.
Ketakutan akan kehilangan eksistensi inilah yang memunculkan kegelisahan. Gambaran ini sesungguhnya mengindikasikan bentuk kegelisahan Nano akan kehilangan eksistensi dirinya. Apa yang sudah diidentifikasi sebagai identitas dirinya menjadi tidak penting lagi karena ketakutan hilangnya orang-orang yang berada disekitarnya. Diri menjadi kehilangan objek hasratnya, yakni objek $a$-nya. Pada kondisi inilah $I d$ dalam diri mencuat, salah satunya adalah naluri kematian pada diri manusia itu.

Naluri kematian itu digambarkan melalui tindakan tokoh-tokoh dalam novel CC ini seperti Hilman, Nina, dan Arsena. Dalam novel sebelumnya (CM) tindakan ini dapat dilihat pada tokoh Nancy dan Arsena yang mencoba melakukan tindakan bunuh diri sebanyak tiga kali. Akan tetapi, Id tersebut tidak membutuhkan bahasa, tidak mengenal hukum, aturan-aturan, prinsip, apalagi budaya. Kematian dengan jalan bunuh diri yang dilakukan oleh Arsena secara sadarnya tetap menyimpan atau mengindikasikan hasrat Nano dalam memandang kematian tersebut. Hasrat Nano ini terdeteksi dari sudut pandangnya mengenai jalan kematian tersebut dengan tetap sebagai manusia yang menghargai kehidupan dan Tuhan (Liyan yang Simbolik).

"Jadi mengapa harus pongah, sombong, dan serakah? Betapa tak berharganya segala yang ada di dunia nyata. Dengan sangat mudah Sang Maha Pencipta bisa menghancurkannya hanya dalam sekejap. Kita semua adalah milik-Nya. "Lalu, apa semua yang kita miliki semasa hidup, hanya kesia-siaan belaka? Tidak. Jika kita tahu cara berterima kasih kepada alam, kehidupan, dan Sang Pencipta Kebidupan... Manusia berbuat, lalu ada bukti akibat perbuatan. Tapi pada saatnya,bukti perbuatan akan lenyap jadi pasir, jadi debu, jadi angin. Meski begitu, manusia wajib berbuat, terus bekerja. Sebab itu adalah salah satu bentuk rasa terima kasih kepada alam, kebidupan, dan Sang Pencipta Kebidupan." (CC, hlm. 333).

Dari kutipan tersebut adanya indikasi pengejawantahan penanda yang menjadi hasrat Nanoakan seorangyang berterimakasih, seorang yang rendah hati, berbuat baik atau melakukan 
sesuatu yang terbaik untuk kehidupan. Dalam tatanan Simbolik Nano meyakini bahwa Liyan yang Simbolike (Alam, Masyarakat, dan Tuhan) akan mencintai keberadaannya. Oleh karena itu, apa yang digambarkan oleh Nano tentang kematian yang ada di dalam novel ini adalah kegelisahannya akan kehilangan objek $a$.

Kematian yang menjadi gambaran dalam novel ini adalah metafora Nano akan kehilangan eksistensi diri atau hilangnya pengakuan. Gagasan yang dibuat Nano tentang bunuh diri sama halnya dengan gagasan Kierkegaard tentang 'kemungkinan': kemungkian mati, kemungkinan dikastrasi, kemungkinan kena musibah, dst. Intinya, karena merasa ada yang kurang dalam diri Nano, fantasi kehancuran eksistensial akan selalu menghantui. Oleh karena inilah Lacan mengatakan bahwa kecemasan muncul saat "the lack is itself lacking; anxiety is the lack of a lack."

\section{Kesimpulan}

Dari pembahasan yang telah dilakukan terhadap novel CC, dapat disimpulkan bahwa hasrat Nano menjadi seorang penulis atau seniman adalah hasratnya keluar dari linearitas Simbolik. Akan tetapi, alih-alih keluar dari satu Simbolik, justru terjebak pada simbolik yang lain. Menjadi penulis dan seniman menuntunnya secara tak sadar pada penandapenanda simbolik lainnya seperti penulis yang 'pantang menyerah', 'ulet', 'konsisten', 'tekun', 'rajin', dsb. Bagi Nano menjadi penulis dan seniman merupakan anchoring point akan keambiguitasan dirinya. Mendirikan kelompok teater dengan menjadi penulis lakon dan menyutradarainya yang ia dapatkan dari citraan Rendra, Putu Wijaya, Arifin C Noor, dan Teguh Karya merupakan hasratnya akan keutuhan yang ontologis bagi identitas tersebut. Menjadi penulis dan seniman, seolah membuat Nano menemukan kebebasan dari berbagai jerat dan belenggu Yang Simbolik. 'Kebebasan' menjadi objek a Nano untuk mendapatkan jouissance bagi dirinya.

\section{Daftar Pustaka}

Althusser, Louis. 2010. Tentang Ideologi: Marxisme Strukturalis, Psikoanalisis, Cultural Studies, terj. Olsy Vinoli Arnof. Yogyakarta: Jalasutra

Anwar, Syaiful. 2005. N. Riantiarno: Dari Rumah Kertas ke Pentas Dunia. Jakarta: fftv ikj press.

Audifax. 2006. "Lara Croft: Antara Hasrat Menjadi dan Hasrat Memiliki" dalam Adlin, Alfatri (ed). Menggeledah Hasrat: Sebuah Pendekatan Multiperspektif. Yogyakarta: Jalasutra.

Bracher, Mark. 2009. Jacques Lacan, Diskursus dan Perubahan Sosial: Pengantar Kritik-Budaya Psikoanalisis, terj. Gunawan Admiranto. Yogyakarta: Jalasutra.

Faruk. 2012. Metode Penelitian Sastra: Sebuah Penjelajahan Awal. Yogyakarta. Pustaka Pelajar.

2012. Sastra sebagai Produk dan Produsen Kebudayaan Sebuah (De-)Konstruksi. Yogyakarta: Yasayo.

Hartono, Agustinus. 2007. Skizoanalisis Deleuze + Guattari: Sebuah Pengantar Genealogi Hasrat. Yogyakarta: Jalasutra.

Hill, Philip. 2002. Lacan Untuk Pemula. Yogyakarta: Kanisius

Lacan, Jacques. 1977. Ecrits: A Selection, terj. Alan Sheridan. London: Tavistock.

- 1988. The Seminar of Jacques Lacan, Book II. The Ego in Freud's Theory and in the Technique of Psycoanalysis, 1954-1955, peny. J-A. Miller, terj. S. Tomaselli. NY, London: W.W. Norton \& Company.

Piliang, Yasraf Amir. 2006. "Antara Minimalisme dan Pluralisme Manusia Indonesia dalam Serangan Posmodernisme" dalam Adlin, Alfatri (ed). Menggeledah Hasrat: Sebuah Pendekatan Multiperspektif. Yogyakarta: Jalasutra.

Riantiarno, N. 2005. Cermin Bening. Jakarta: Grasindo. 1997. Catatan ulang tahun ke-20 Teater Koma, 1977-1997. Jakarta: Kumpulan Tulisan Makalah. Tidak diterbitkan.

Sarup, Madam. 2011. Panduan Pengantar Untuk Memahami Postrukturalisme dan Posmodernisme, terj. Medhy Aginta Hidayat. Yogyakarta: Jalasutra. 